<원 저>

\title{
Identification of two cytopathogenic agents, Mycoplasma hyorhinis and mammalian orthoreovirus 3 based on modified particle associated nucleic acids PCR
}

\author{
Hye Kwon Kim ${ }^{1}$, Hyoung Joon Moon ${ }^{2}$, Seong Jun Park ${ }^{1}$, Se Mi Rho', Jae Yeon Han ${ }^{1}$, \\ Van Giap Nguyen ${ }^{1}$, Bong Kyun Park ${ }^{1, *}$ \\ ${ }^{1}$ College of Veterinary Medicine and BK21 Program for Veterinary Science, \\ Seoul National University, Seoul 151-742, Korea \\ ${ }^{2}$ Research Unit, Green Cross Veterinary Products, Yong-in 449-903, Korea
}

(Accepted: March 29, 2011)

\begin{abstract}
Swine diseases could be caused by unrecognized or minor pathogens. In this study, two unknown cytopathogenic agents were isolated from swine, through cell culture. In order to identify these two cytopathogenic agent (designated CP129 and \#2045-7), a particle associated nucleic acids PCR (PANPCR) from previous paper was used with simple modification. The cloning procedure was more specified in this study by adding cell control system. According to the modified PAN-PCR, two and four agentsspecific DNA sequences were obtained from CP129 and \#2045-7, respectively, and they were identified as Mycoplasma (M.) hyorhinis and Mammalian orthoreovirus by nucleotide BLAST. Since M. hyorhinis (CP129) was filterable and non-visible by microscope, this unusual virus-like nature of $M$. hyorhinis (CP129) was discussed. Especially, the reovirus (\#2045-7) was a serotype 3 and a triple reassortant among three serotypes of reoviruses. It was grouped with recently reported reoviruses from disease cases (swine, human and feline), based on the genetic analysis of L1 and S1 partial sequences. In conclusion, two unknown cytopathogenic agents were successfully identified using modified PAN-PCR with cell control system and they were characterized in this study.
\end{abstract}

Keywords : mammalian orthoreovirus, Mycoplasma hyorhinis, PAN-PCR, pig, unknown

\section{Introduction}

Virus infection in swine industry has been a main issue for history. Recently viruses such as porcine reproductive and respiratory syndrome virus (PRRSV) and porcine circovirus (PCV) are regarded as crucial pathogens for swine industry. Until now, several new swine viruses has been isolated and identified. Therefore, it is important to consider various possible swine viruses for the diagnosis of swine diseases.

There might be limitation for the detection of specific pathogens, such as unknown and minor pathogens. Virus isolation using diverse cultured cells can be a way to find unknown swine viruses. Since the virus isolation has broader spectrum for viral detection than targetspecific methods, such as polymerase chain reaction and immunoassay, several novel viruses were identified from unknown viral isolates infecting specific cell types during the virus isolation.

Identification of unknown agents from cell culture can be achieved by random polymerase chain reaction (random-PCR) approach. Many efficient random-PCR methods were developed and improved by previous researchers $[1,3,8,26]$. With diverse random-PCR approaches, previously unknown viruses were successfully identified in humans $[2,8,25]$. In this study, two unknown cytopathogenic agents isolated from pigs were studied. Since they were negative for several major swine pathogens, they were identified by particleassociated nucleic acid PCR (PAN-PCR) method [21]. By sequence analysis and additional study, the unknown agents were also confirmed and characterized.

\footnotetext{
*Corresponding author

Tel: +82-2-880-1255, Fax: +82-2-885-0263

E-mail: parkx026@snu.ac.kr
} 


\section{Materials and Methods}

\section{Sample information}

The CP129 was isolated from a 14 days old pig presented hepatic necrosis and sudden death in 2010. The \#2045-7 was isolated from the serum of an aborted sow in 2005. They were consistently inducing cytopathogenic changes at serial passage in Vero and MARC145 cell lines.

To identify the viral agents, they were tested by PCR or RT-PCR which were routinely used for laboratory detection of swine viruses. No positive results were found for PRRSV, PCV2, classical swine fever virus (CSFV), pseudorabies virus (PRV), Hemagglutinating encephalomyelitis virus (HEV), Tescho virus, porcine enterovirus $\mathrm{A}$ and $\mathrm{B}$.

\section{Virus isolation and sample preparation}

In the case of CP129, the Vero cell monolayer was prepared in DMEM (3\% FBS). The 10\% tissue homogenate in DMEM was filtered through $0.2 \mu \mathrm{m}$ filter (Sartorius, Germany) and inoculated to Vero cell monolayer previously washed with PBS ( $\mathrm{pH}$ 7.4). Two hours after incubation, the Vero cells were PBS-washed and maintained with fresh DMEM (3\% FBS) for 5 days. The cytopathic effect (CPE) was observed after 3 times of blind passage. For \#2045-7, 10\% serum dilution with DMEM (filtered, $0.2 \mu \mathrm{m}$ ) and MARC-145 cells (cloned from MA-104) were used for virus isolation [13]. After inoculation, the MARC-145 cells were maintained with fresh DMEM (5\% FBS) for 3 to 5 days until CPE was observed.

When CPE was observed over $80 \%$, Vero and MARC 145 cell infected with CP 129 and \#2045-7, respectively were frozen for the PAN-PCR. To select agent-specific amplicons more efficiently, mock-infected cells were also included during this step. After two freezing and thawing of the infected cell, the cell lysate was centrifuged at $3,000 \mathrm{rpm}$ for $20 \mathrm{~min}$ at $4^{\circ} \mathrm{C}$ and the supernatant was filtered through $0.2 \mu \mathrm{m}$ filter. The 20 $\mathrm{mL}$ of filtered supernatant was ultracentrifuged at 35,000 rpm for $1 \mathrm{~h}$ and concentrated into $500 \mu \mathrm{L}$ of solution using PBS. The concentrated stock was re-centrifuged at 3,000 rpm for $20 \mathrm{~min}$ at $4^{\circ} \mathrm{C}$ and the supernatant was used for DNA and RNA extraction.

\section{DNA and RNA extraction}

Before DNA and RNA extraction, the semipurified samples were treated with 10 unit of DNase I (Promega, USA) and RNase A (Biosesang, Korea) for $30 \mathrm{~min}$ at $37^{\circ} \mathrm{C}$. The enzymatic reaction was stopped by EDTA. The DNase I-treated samples were used for DNA and RNA extraction. For the DNA extraction, $500 \mu \mathrm{L}$ of cell lysis buffer containing $27 \%$ sucrose, $1 \times$ saline sodium citrate (SSC) $(15 \mathrm{mM}$ trisodium citrate and $0.15 \mathrm{M} \mathrm{NaCl}$, $\mathrm{pH}$ 7.0), $1 \mathrm{mM}$ EDTA, $1 \%$ sodium dodecyl sulfate (SDS) and $200 \mu \mathrm{g} / \mathrm{mL}$ of proteinase $\mathrm{K}$, was mixed with $200 \mu \mathrm{L}$ of sample and incubated for $1 \mathrm{~h}$ at $56^{\circ} \mathrm{C}$. Following the incubation, $200 \mu \mathrm{L}$ mixture of phenol, chloroform and isoamyl alcohol $(25: 24: 1)$ was added and vortexed. The vortexed sample was then centrifuged at $12,000 \mathrm{rpm}$ for $15 \mathrm{~min}$ and $500 \mu \mathrm{L}$ of the aqueous phase was mixed with the same volume of isopropyl alcohol, followed by incubation at $-20^{\circ} \mathrm{C}$ for $2 \mathrm{~h}$. After centrifuge at $12,000 \mathrm{rpm}$ for $10 \mathrm{~min}$, the pellet was washed with $70 \%$ ethanol in distilled water and centrifuged again under the same condition. The pellet from which the alcohol was completely removed was resuspended in Tris-EDTA buffer ( $\mathrm{pH}$ 8.0).

For the RNA extraction, Trizol LS (Invitrogen, USA), a commercially available RNA extraction solution was used. The overall procedure was followed by manufacturer's recommendation.

\section{Random polymerase chain reaction (PCR)}

The PAN-PCR method established by Stang et al. [21] was slightly modified and used for this study. For the cDNA synthesis, a commercial cDNA synthesis kit (MMLV reverse transcriptase kit; Invitrogen, USA) was used with $10 \mu \mathrm{L}$ of RNA and $2 \mu \mathrm{L}$ of $10 \mathrm{pmol} / \mu \mathrm{L}$ of primer K-random (5'-GAC CAT CTA GCG ACC TCC ACMNNMNM-3') following manufacturer's instruction. The prepared DNA and cDNA were used for T4 DNA polymerase reaction (Takara, Japan). Briefly, $7 \mu \mathrm{L}$ of mixture containing $1 \mu \mathrm{L}$ of $10 \times$ buffer, $1 \mu \mathrm{L}$ of $0.1 \%$ BSA solution, $1 \mu \mathrm{L}$ of $2.5 \mathrm{mM}$ dNTP, $2 \mu \mathrm{L}$ of primer Krandom $(10 \mathrm{pmol} / \mu \mathrm{L})$ and $2 \mu \mathrm{L}$ of $3^{\circ}$ distilled water, was mixed with $2 \mu \mathrm{L}$ of template DNA or cDNA, followed by incubation at $70^{\circ} \mathrm{C}$ for $5 \mathrm{~min}$ and stored at $37^{\circ} \mathrm{C}$ until the next procedure. After adding $1 \mu \mathrm{L}$ of $\mathrm{T} 4$ DNA polymerase, they were incubated at $12^{\circ} \mathrm{C}$ for $20 \mathrm{~min}$ and the reaction was stopped by incubating at $75^{\circ} \mathrm{C}$ for 10 min. The final reactant $(10 \mu \mathrm{L})$ was used for the next PCR reaction.

For the random amplification, primer $\mathrm{K}$ (5'-GAC CAT CTA GCG ACC TCC AC-3') was used. For the PCR, 
PCR premix kit (Intron, Korea) was used following manufacturer's manual. Briefly, $2 \mu \mathrm{L}$ of each primer $\mathrm{K}$ $(10 \mathrm{pmol} / \mu \mathrm{L})$ and template were mixed with i-star mastermix solution (Intron, Korea) and added to premix tube. The PCR reaction was performed as followed; $95^{\circ} \mathrm{C}$ for $5 \mathrm{~min}, 40 \mathrm{cycles}$ of $95^{\circ} \mathrm{C}$ for $30 \mathrm{sec}, 55^{\circ} \mathrm{C}$ for $30 \mathrm{sec}, 72^{\circ} \mathrm{C}$ for $60 \mathrm{sec}$ and $72^{\circ} \mathrm{C}$ for $5 \mathrm{~min}$. The amplified PCR products were separated by electrophoresis using $1 \%$ agarose gel containing $\mathrm{EtBr}$ and visualized under UV light.

\section{Cloning and sequence analysis}

The randomly amplified DNA fragments were cloned to TA vector and subsequently transformed to the competent cells (DH5a), using a commercial TA cloning kit (Topcloner TA kit; Enzynomics, Korea). The selected recombinant plasmids were sequenced using M13F(-20) and M13R universal primers. The sequencing was performed by Genotech company in Korea.

The obtained sequences were aligned and processed to remove the overlapping sequences, using CLUSTAL X v1.81 and BioEdit program [9, 22]. The final sequences were analyzed by nucleotide BLAST search tool (NCBI, USA).

\section{Confirmative study for Mycoplasma hyorhinis (CP129) and mammalian orthoreovirus (\#2045-7)}

To confirm the cytopathogenic agent (CP129) as Mycoplasma (M.) hyorhinis, M. hyorhinis-specific PCR was applied [15]. Also, the cytopathogenic changes were compared between two groups, Mycokill (PAA, USA)treated and non-treated groups. The Mycokill was added to the maintenance media for incubation time. Since $M$. hyorhinis was known to induce hemolysis [18], the supernatant of CP129-infected Vero cells were inoculated to blood agar (Komed, Korea) and compared to that of the mock-infected vero cells.

In the case of mammalian orthoreovirus (\#2045-7), serotype-specific RT-PCR method was used to confirm and characterize the virus [6]. Since the \#2045-7 isolate was revealed as serotype 3 in the RT-PCR, the partial S1 segment genome was amplified by RT-PCR and subsequently sequenced for genetic analysis, using previously published primers, ENT-S1-R3F (5'-gCTAT TggTCggATggAT-3') and S1-R3R (5'-CTgAAgTCCAC CRTTTTgWA-3') [6]. The partial sequence of L1 obtained from random amplification was also compared with reference sequences. The obtained L1 and S1 partial sequences were aligned with previously published type 3 reoviruses using CLUSTAL X v1.81 [22]. Phylogenetic and molecular evolutionary analyses were conducted using MEGA version 3.1 [14].

\section{Results}

\section{Cytopathogenic effect of the two unknown agents}

To exclude bacterial contamination, the cytopathogenic agents were filtered through $0.2 \mu \mathrm{m}$ filter (Sartorius, Germany) in every passage. The cytopathogenic changes were continuously observed in the infected cells with filtered inoculum. The cytopathogenic changes of CP129infected Vero cell were rapid acidification of medium and detachment of the cells (Fig. 1). The CP129 also induced cell detachment, when it was inoculated to MARC-145 cells. In the case of \#2045-7, the cytopathogenic changes were observed as cell aggregations and detachment (Fig. 2). The \#2045-7 was also capable of inducing cytopathogenic changes in MDBK cells. After
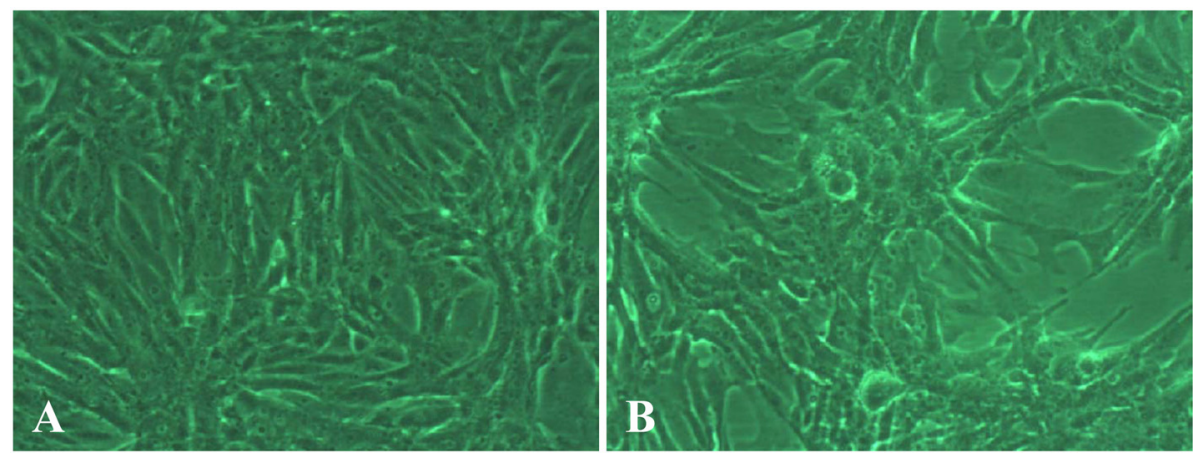

Fig. 1. Cytopathogenic effect of CP129-infected Vero cells. Captured images were obtained from the Inverted microscope. $\times 100$. (A) control, (B) CP129-infected vero cells. 

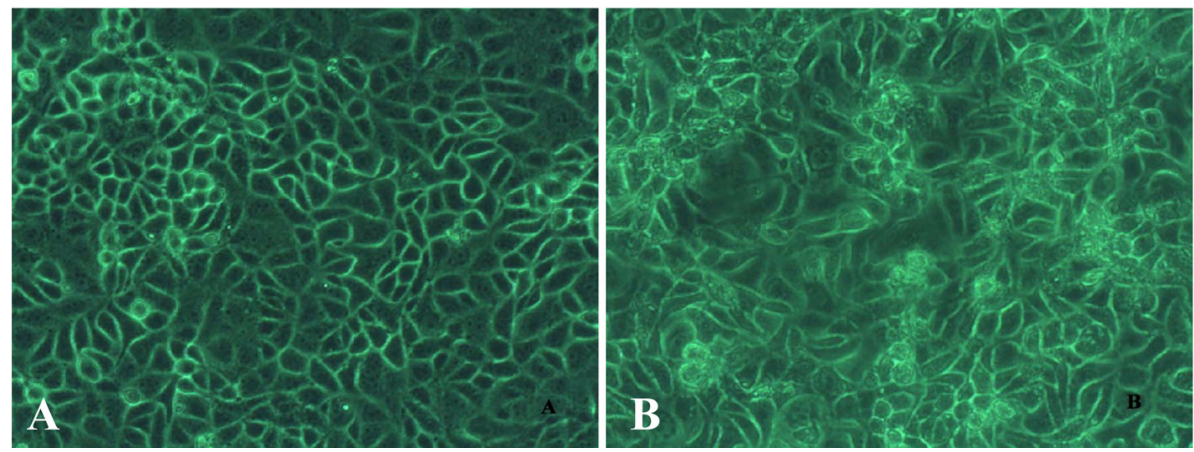

Fig. 2. Cytopathogenic effect of \#2045-7-infected MARC-145 cells. Captured images were obtained from the Inverted microscope. $\times 100$. (A) control, (B) \#2045-7-infected MARC-145 cells.

the three passages, these two agents induced the obvious cytopathogenic changes $72 \mathrm{~h}$ after inoculation.

\section{Random amplification of two cytopathogenic agents using modified PAN-PCR method}

To increase the efficiency, cell control was also included. Comparing to the cell control, the cytopathogenic agentspecific amplicons were selected. The agents-specific DNA fragments were observed from the PNA-PCR products using RNA (Fig. 3). In the case of PAN-PCR products using DNA, it was hard to identify the agentsspecific bands in the electrophoresis, which might be due to high concentration of DNA fragments. However, agents-specific bands were clearly observed in PANPCR products from RNA. For the CP129, agent-specific bands were observed in 300 400 and 500 600 base pair regions. The agent-specific bands were observed in 700 and 900 1,000 base pair region in the \#2045-7 sample. Even though two agents were treated with RNase A and DNase I, non-specific bands were also observed from cell control. The agents-specific bands from RNA/ cDNA-based PAN-PCR were purified using Gelextraction method and further processed for TA cloning and transformation.

\section{Sequencing and BLAST analysis of the agents- specific amplicons}

Two and four independent nucleotide sequences were obtained from CP129 and \#2045-7 isolates, respectively. The BLAST searching results were presented in Table 1. The two sequences from CP129 were partial $23 \mathrm{~S}$ and 16 S ribosomal RNA of $M$. hyorhinis, showing $99 \%$ of identity. In the case of \#2045-7 isolate, four independent sequences were all matched to mammalian orthoreovirus.

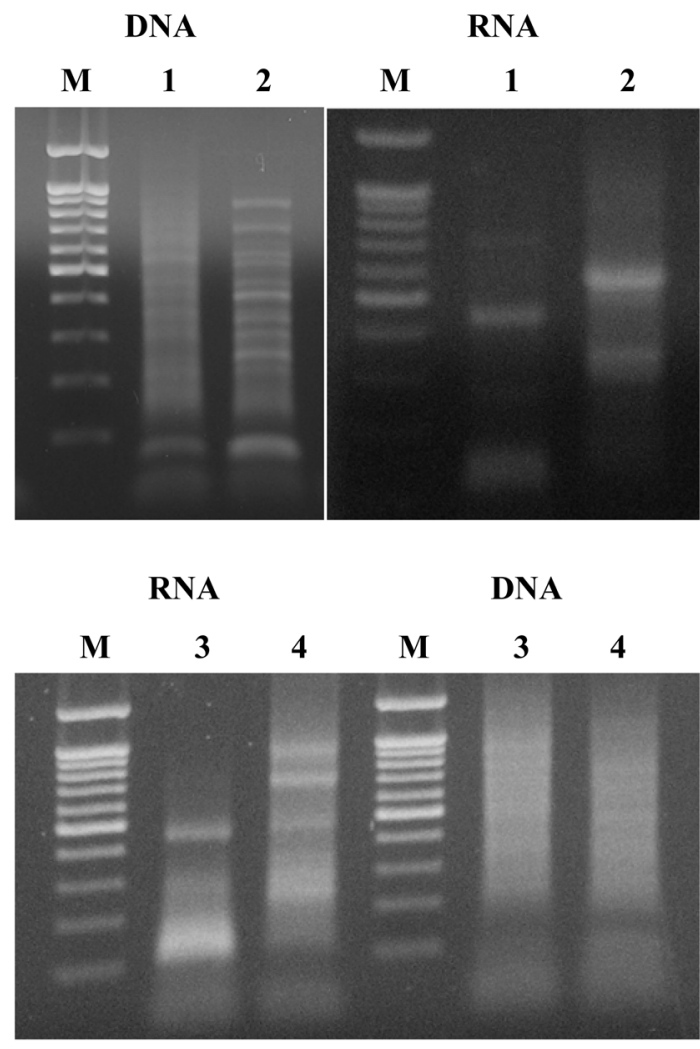

Fig. 3. Random amplification results of the two cytopathogenic agents using PAN-PCR. The PAN-PCR results from DNA or RNA were presented. M: 100 bp ladder, 1: mockinfected Vero cells, 2: CP129-infected Vero cells, 3: mockinfected MARC-145 cells, 4: \#2045-7-infected MARC-145 cells.

Two partial sequences had $96 \%$ identity with mammalian orthoreovirus 1 Neth/85 core-spike protein lambda-2 (L2) mRNA (GenBank Accession no. AF378004). The 
Table 1. The megablast results of the amplified DNA fragment sequences from cytopathogenic agents

\begin{tabular}{|c|c|c|c|c|}
\hline Agents & DNA fragment & Source & BLAST search & BLAST information \\
\hline \multirow{2}{*}{ CP129 } & 11 seq $(574 \mathrm{bp})$ & RNA & AF182581 (99\%) & Mycoplasma hyorhinis gene for $23 \mathrm{~S}$ ribosomal RNA \\
\hline & $12 \operatorname{seq}(317 \mathrm{bp})$ & RNA & GU227401 (99\%) & Mycoplasma hyorhinis strain USP83TRA 16S ribosomal RNA gene \\
\hline \multirow{4}{*}{ \#2045-7 } & 21 seq $(626 \mathrm{bp})$ & RNA & AF378004 (96\%) & $\begin{array}{l}\text { Mammalian orthoreovirus } 1 \mathrm{Neth} / 85 \text { core-spike protein lambda- } 2 \\
\text { (L2) mRNA }\end{array}$ \\
\hline & $22 \operatorname{seq}(381 \mathrm{bp})$ & RNA & GU196312 (97\%) & Mammalian orthoreovirus 2 segment S3 nonstructural protein gene \\
\hline & $23 \operatorname{seq}(674 \mathrm{bp})$ & RNA & GU196306 (98\%) & Mammalian orthoreovirus 2 segment L1 lambda-3 protein gene \\
\hline & $24 \operatorname{seq}(371 \mathrm{bp})$ & RNA & AF378004 (96\%) & $\begin{array}{l}\text { Mammalian orthoreovirus } 1 \mathrm{Neth} / 85 \text { core-spike protein lambda- } 2 \\
\text { (L2) mRNA, complete cds }\end{array}$ \\
\hline
\end{tabular}

Neucleotide sequences of \#2045-7 were in Genbank accession no. HQ166025-HQ166028.
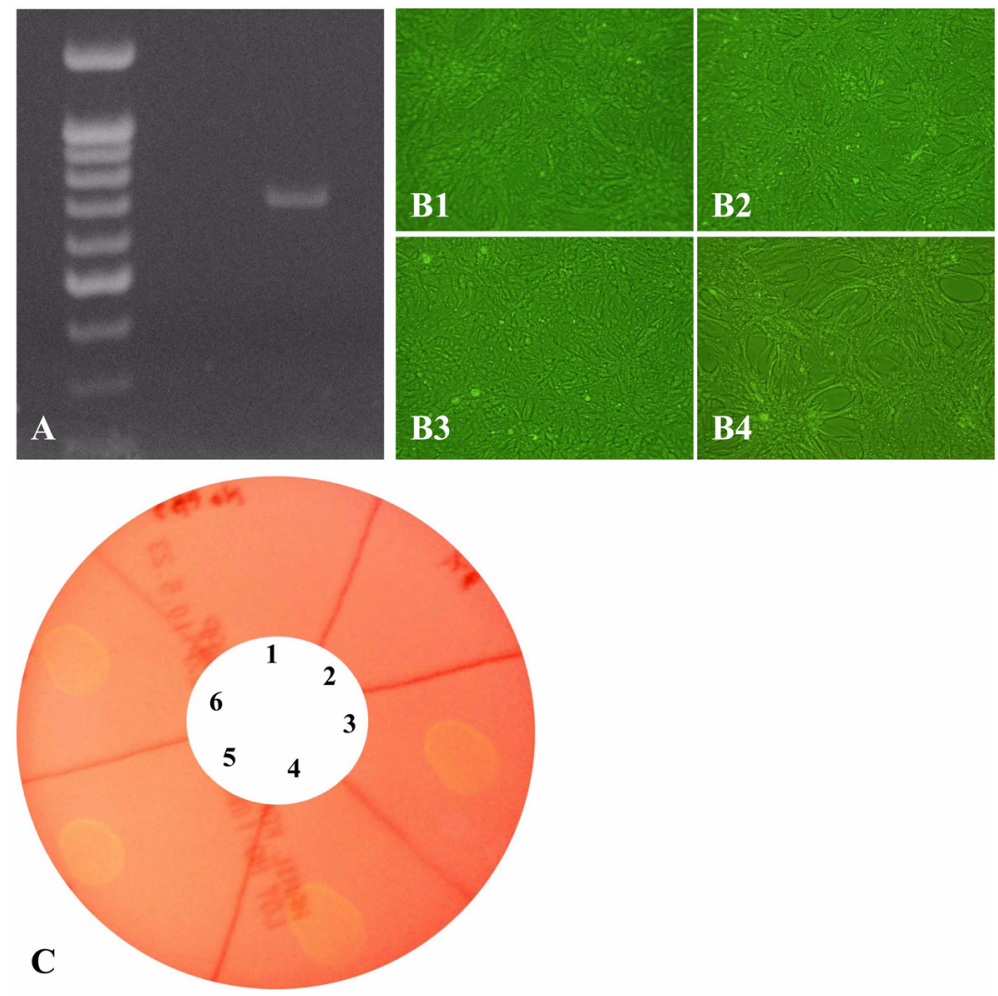

Fig. 4. Confirmation and characterization of the identified Mycoplasma (M.) hyorhinis, CP129 strain. (A) M. hyorhinisspecific PCR. M: 100 bp ladder, 1: mock-infected Vero cells, 2: CP129-infected Vero cells. (B) Inhibitory effect of MycoKill treatment for cytopathogenic changes induced by M. hyorhinis, CP129 strain. 1: mock-infected and Mycokill-treated Vero cells, 2: CP129-infected and Mycokill-treated Vero cells, 3: mock-infected Vero cells without MycoKill treatment, 4: CP129infected Vero cells without MycoKill treatment. (C) alpha-like hemolysis induced by M. hyorhinis, CP129 strain on sheep blood agar. 1: mock-infected/no FBS supplement, 2: mock-infected/5\% FBS, 3: CP129-infected/no FBS, 4: CP129-infected/ 1\% FBS, 5: CP129-infected/3\% FBS, 6: CP129-infected/5\% FBS.

other two partial sequences were similar to mammalian orthoreovirus 2 segment S3 nonstructural protein gene (GU196312) and segment L1 lambda-3 protein gene (GU196306), showing $97 \%$ and $98 \%$ identity, respectively.

\section{Confirmation and characterization of $M$. hyorhi- nis (CP129)}

The M. hyorhinis-specific bands were observed in CP129-infected Vero cells, while no bands were observed 


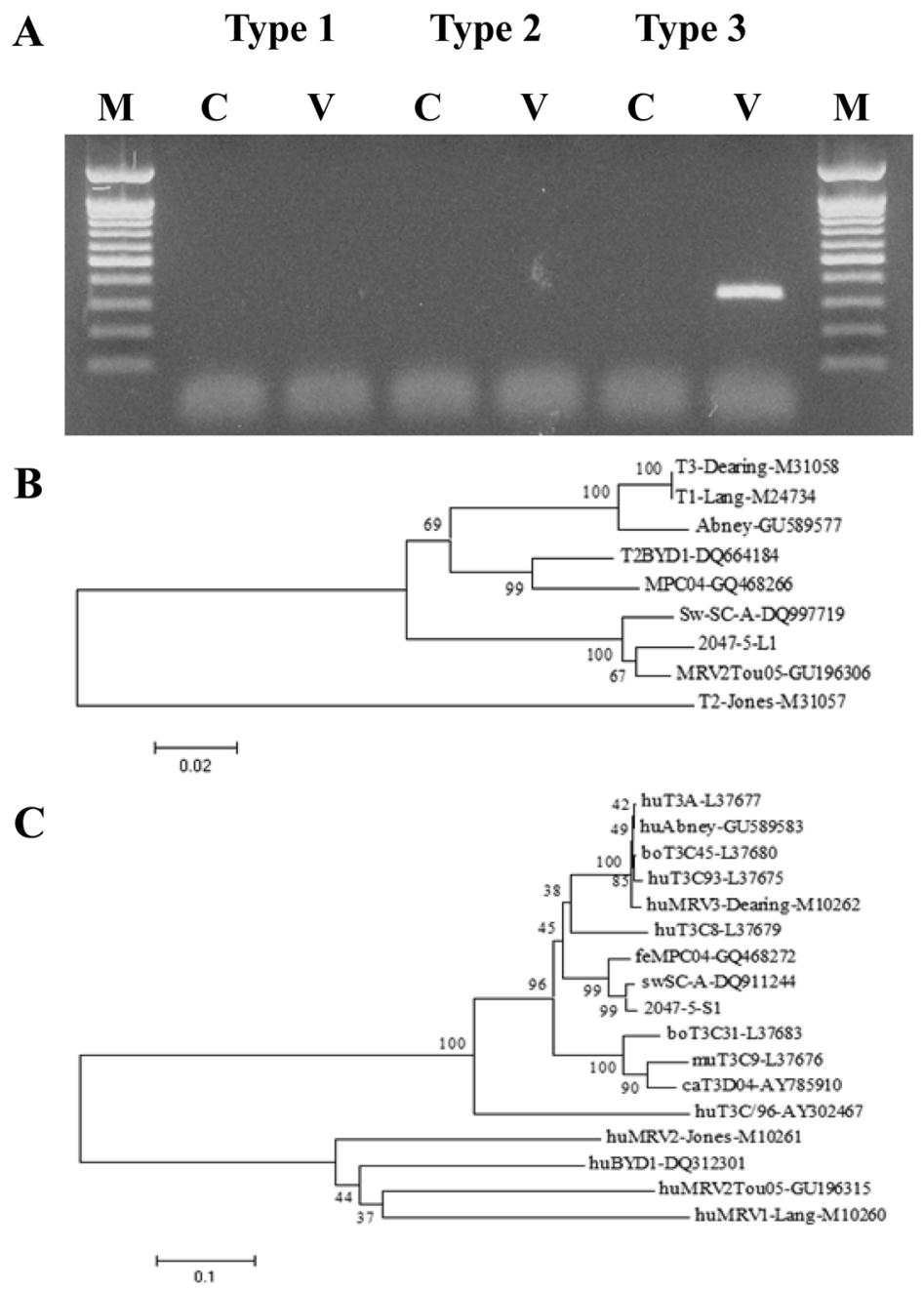

Fig. 5. Confirmation and phylogeny of the identified Mammalian orthoreovirus, \#2045-7 strain. (A) RT-PCR for serotyping of \#2045-7. M: 100 bp ladder, C: mock-infected MARC-145 cells, V: \#2045-7-infected MARC-145 cells. (B) Neighborjoining tree based on partial L1 sequences (674 bp) of \#2045-7 and reference sequences. (C) Neighbor-joining tree based on partial S1 sequences (458 bp) of \#2045-7 and reference sequences. All of reference sequences were indicated by Genbank accession number.

in mock-infected Vero cells by $M$. hyorhinis-specific PCR (Fig. 4A). Furthermore, when the CP129-inoculated Vero cells were incubated with maintenance medium containing MycoKill solution (PAA, USA) which was used for Mycoplasma spp. eradication from cell lines, the cytopathogenic changes were reduced (Fig. 4B). When the supernatant of CP129-infected Vero cells was inoculated on the sheep blood agar (Komed, Korea) at $37^{\circ} \mathrm{C}$ for 4 days, CP129-specific hemolysis (alpha-like hemolysis) was observed (Fig. 4C), while no changes were observed from mock-infected Vero cells. No obvious differences of hemolysis were also observed, when the supernatant of CP129-infected Vero cells incubated with different concentration of FBS $(0,1,3$ and $5 \%)$ were inoculated on the blood agar.

\section{Confirmation and characterization of mammalian orthoreovirus (\#2045-7)}

In the serotype-specific RT-PCR, the \#2045-7 isolate was identified as a type 3 reovirus (Fig. 5A). The phylogenetic analysis of \#2045-7 based on partial L1 segment sequences (674 bp, Fig. 5B) showed that \#2045- 
7 made an unique subgroup with recent reoviruses originated from swine (SC-A, DQ997719, serotype 3) and human (Tou05, GU196306, serotype 2). The Tou05 reovirus was reported as human-swine reassortant according to the Genbank information. The nucleotide sequence identity among theses viruses were 97.3 97.7\%. The partial L1 segment sequences of \#2045-7 showed $88.4 \%, 75.8 \%$ and $87.9 \%$ of nucleotide identity with type 1,2 and 3 of reference reoviruses, respectively. The partial S1 sequences of \#2045-7 had 95.4\% and $97.8 \%$ of identities with reoviruses originated from swine (SC-A, DQ911244, serotype 3) and feline (MPC04, GQ468272, serotype 3). In the phylogenetic analysis of partial S1 sequences $(458 \mathrm{bp})$, these reoviruses were grouped in the same clade (Fig. 5C). The partial S1 sequences did not discriminate serotype 1 and 2 in the phylogenetic tree using neighbor-joining method.

\section{Discussion}

In this study, we tried to identify two unknown cytopathogenic agents isolated from the cultured cell lines with PAN-PCR method [21], which is easy to perform and provided a good efficiency. To increase the specificity during the PAN-PCR, cell control system was used in this study. Although DNase I and RNase A were treated, DNA or RNA originated from cell lines might be affect to the result. Therefore, the target-specific bands could be efficiently selected for the sequencing using cell control system. M. hyorhinis (CP129) and mammalian orthoreovirus 3 (\#2045-7) were successfully identified using modified PAN-PCR method in this study. Notably, M. hyorhinis isolated in this study showed a virus-like property because it could be filterable for $0.2 \mu \mathrm{m}$ filter and induce cytopathogenic changes in the Vero cells, which were differed from bacterial contamination. This virus-like nature of $M$. hyorhinis was previously reported and characterized [5, 7, 20]. Therefore, the test for M. hyorhinis should be considered for the specific viruses showing cytopathogenic changes in cultured cell lines.

Although obvious relationship between disease and etiology was not demonstrated in this study, M. hyorhinis was isolated from a young pig with severe hepatic necrosis without other known swine virus infections. $M$. hyorhinis is known as common inhabitant in the respiratory tract of pigs, but occasionally related with polyserositis and arthritis in young pigs $[11,16]$. However, recently,
M. hyorhinis was reported to be associated with abortion and postweaning mutisystemic wasting syndrome [12, 20]. Furthermore, alpha-hemolytic feature of M. hyorhinis found in this study raised concerns about its pathogenic property. Therefore, further etiological study of $M$. hyorhinis might be needed in swine species.

The mammalian orthoreoviruses can be divided into 3 serotypes [19]. All serotypes could infect diverse mammals including human but they were thought as minor pathogens [23]. In this study, \#2045-7 isolate was identified as type 3 reovirus by RT-PCR for serotyping [6]. It was revealed as a triple reassortant of all three serotypes by genetic analysis (L1 from type 2, L2 from type 1 and S1 from type 3). In the phylogenetic analysis of partial L1 and S1 segments, it was grouped with recently reported reoviruses from swine (2006, DQ997719), human (2009, GU196306) and feline (2009, GQ468272) species rather than prototypes or classical reovirus isolates. Furthermore, new suggestions about the relationship between recent reoviruses and human diseases were made by several research groups [10, 24]. Therefore, additional studies about recent reoviruses should be followed to monitor their pathogenic changes.

While type 3 reovirus infection was reported to be associated to a case of meningitis in human and cat $[4$, 24], there are few studies about the pathogenicity of type 3 reovirus in pigs. Mammalian orthoreovirus 3 was reported to be related with abortion and pulmonary lesions in pigs [17]. Since it was not clear that the identified reovirus was a causative agent of abortion in this study, experimental infection studies should be followed to demonstrate its etiology.

\section{Conclusion}

In conclusion, two cytopathogenic agents were identified as M. hyorhinis and mammalian orthoreovirus 3 by modified PAN-PCR method. Adding cell controls used for PAN-PCR, the agent-specific amplicons were more specifically selected. Although novel viruses were not found in this study, the modified PAN-PCR-based method can be useful to identify and characterize unknown cytopathogenic agents in the cultured cells.

\section{Acknowledgments}

This study was supported by a grant (Code\# 20070401034009) from the Biogreen 21 Program, Rural 
Development Administration, Korea.

\section{References}

1. Allander T, Emerson SU, Engle RE, Purcell RH, Bukh J. A virus discovery method incorporating DNase treatment and its application to the identification of two bovine parvovirus species. Proc Natl Acad Sci USA 2001, 98, 11609-11614.

2. Allander T, Tammi MT, Eriksson M, Bjerkner A, Tiveljung-Lindell A, Andersson B. Cloning of a human parvovirus by molecular screening of respiratory tract samples. Proc Natl Acad Sci USA 2005, 102, 12891-12896.

3. Clem AL, Sims J, Telang S, Eaton JW, Chesney J. Virus detection and identification using random multiplex (RT)-PCR with 3'-locked random primers. Virol J 2007, 4, 65.

4. Csiza CK. Characterization and serotyping of three feline reovirus isolates. Infect Immun 1974, 9, 159-166.

5. Darai G, Flügel RM, Zöller L, Matz B, Kreig A, Gelderblom H, Delius H, Leach RH. The plaqueforming factor for mink lung cells present in cytomegalovirus and herpes-zoster virus stocks identified as Mycoplasma hyorhinis. J Gen Virol 1981, 55, 201205.

6. Decaro N, Campolo M, Desario C, Ricci D, Camero M, Lorusso E, Elia G, Lavazza A, Martella V, Buonavoglia C. Virological and molecular characterization of a mammalian orthoreovirus type 3 strain isolated from a dog in Italy. Vet Microbiol 2005, 109, 19-27.

7. Gagnon CA, Tremblay D, Tijssen $P$, Venne MH, Houde A, Elahi SM. The emergence of porcine circovirus $2 b$ genotype (PCV-2b) in swine in Canada. Can Vet J 2007, 48, 811-819.

8. Goebel SJ, Taylor J, Barr BC, Kiehn TE, CastroMalaspina HR, Hedvat CV, Rush-Wilson KA, Kelly CD, Davis SW, Samsonoff WA, Hurst KR, Behr MJ, Masters PS. Isolation of avian paramyxovirus 1 from a patient with a lethal case of pneumonia. J Virol 2007, 81, 12709-12714.

9. Hall TA. BioEdit: a user-friendly biological sequence alignment editor and analysis program for Windows 95/ 98/NT. Nucleic Acids Symp Ser 1999, 41, 95-98.

10. He C, Pang W, Yong X, Zhu H, Lei M, Duan Q. Experimental infection of macaques with the human reovirus BYD1 strain: an animal model for the study of the severe acute respiratory syndrome. DNA Cell Biol 2005, 24, 491-495.

11. Jayagopala Reddy NR, Wilkie BN, Borgs P, Mallard BA. Cytokines in Mycoplasma hyorhinis-induced arthritis in pigs bred selectively for high and low immune responses. Infect Immun 2000, 68, 1150-1155.

12. Kawashima K, Katsuda $\mathbf{K}$, Tsunemitsu $\mathbf{H}$. Epidemiological investigation of the prevalence and features of postweaning multisystemic wasting syndrome in Japan. J Vet Diagn Invest 2007, 19, 60-68.

13. Kim HS, Kwang J, Yoon IJ, Joo HS, Frey ML. Enhanced replication of porcine reproductive and respiratory syndrome (PRRS) virus in a homogeneous subpopulation of MA-104 cell line. Arch Virol 1993, 133, 477-483.

14. Kumar S, Tamura K, Nei M. MEGA3: Integrated software for molecular evolutionary genetics analysis and sequence alignment. Brief Bioinform 2004, 5, 150163.

15. Lin JH, Chen SP, Yeh KS, Weng CN. Mycoplasma hyorhinis in Taiwan: diagnosis and isolation of swine pneumonia pathogen. Vet Microbiol 2006, 115, 111-116.

16. Magnusson U, Wilkie B, Mallard B, Rosendal S, Kennedy B. Mycoplasma hyorhinis infection of pigs selectively bred for high and low immune response. Vet Immunol Immunopathol 1998, 61, 83-96.

17. Yuan L, Stevenson GW, Saif LJ. Rotavirus and reovirus. In: Straw BE, Zimmerman JJ, D'Allaire S, Taylor DJ (eds.). Disease of Swine. 9th ed. pp. 435454, Iowa State University, Ames, 2006.

18. Ross RF, Karmon JA. Heterogeneity among Strains of Mycoplasma granularum and identification of Mycoplasma hyosynoviae, sp. n. J Bacteriol 1970, 103, 707-713.

19. Sabin AB. Reoviruses: a new group of respiratory and enteric viruses formerly classified as ECHO type 10 is described. Science 1959, 130, 1387-1389.

20. Shin JH, Joo HS, Lee WH, Seok HB, Calsamig M, Pijoan C, Molitor TW. Identification and characterization of cytopathogenic Mycoplasma hyorhinis from swine farms with a history of abortions. J Vet Med Sci 2003, 65, 501-509.

21. Stang A, Korn $\mathbf{K}$, Wildner $\mathbf{O}$, Überla $\mathbf{K}$. Characterization of virus isolates by particle-associated nucleic acid PCR. J Clin Microbiol 2005, 43, 716-720.

22. Thompson JD, Gibson TJ, Plewniak F, Jeanmougin 
F, Higgins DG. The CLUSTAL_X windows interface: flexible strategies for multiple sequence alignment aided by quality analysis tools. Nucleic Acids Res 1997, 25, 4876-4882.

23. Tyler KL. Orthoreviruses and their replication. In: Knipe DM, Howley PM (eds.). Fields Virology. 5th ed. pp. 1729-1745, Philadelphia, Lippincott Williams \& Wilkins, 2001.

24. Tyler KL, Barton ES, Ibach ML, Robinson C, Campbell JA, O'Donnell SM, Valyi-Nagy T, Clarke P, Wetzel JD, Dermody TS. Isolation and molecular characterization of a novel type 3 reovirus from a child with meningitis. J Infect Dis 2004, 189, 1664-1675.

25. van den Hoogen BG, de Jong JC, Groen J, Kuiken T, de Groot R, Fouchier RAM, Osterhaus ADME. A newly discovered human pneumovirus isolated from young children with respiratory tract disease. Nature Med 2001, 7, 719-724.

26. Welsh J, McClelland M. Fingerprinting genomes using PCR with arbitrary primers. Nucleic Acids Res 1990, 18, 7213-7218. 